\title{
SURVEI PRESTASI CABANG OLAHRAGA UNGGULAN KONI KABUPATEN PASER
}

\author{
Muhammad Dzainuddin ${ }^{1}$ \\ Program Studi Pendidikan Jasmani Kesehatan dan Rekreasi \\ e-mail: muhammaddzainuddin@gmail.com ${ }^{1}$
}

\begin{abstract}
The purpose of this study was to determine the Achievement of the Main Sports Branch of KONI Paser Regency. This type of research uses descriptive qualitative research. The sample in this study were KONI management, trainers, and athletes, totaling 10 people. The population in this study is entering a particular social situation, conducting observations and interviews with people who are considered to know about the social situation. The sampling technique uses purposive sampling, while the technique of collecting data uses observation, interviews and documentation (triangulation). Data analysis techniques used in this study were using data reduction, data presentation and drawing conclusions. Based on the results of this study, the researchers concluded that the achievements of the sports branches registered at the KONI Paser Regency were still very minimal, because it has 42 sports that are officially registered at the KONI secretariat, but of the 42 sports branches, only have 5 branches that are superior in accordance with keriteria that has been determined by the KONI related achievements must be continually and continuously, the following branches of sports that are superior KONI Paser Regency are: (1). Swimming, (2). Oars, (3). Sepak Takraw, (4). Tarung Derajat and (5). Taekwondo.
\end{abstract}

Keywords: Achievements and Featured Sports

Abstrak: Tujuan penelitian ini adalah untuk mengetahui Prestasi Cabang Olahraga Unggulan KONI Kabupaten Paser. Jenis penelitian ini menggunakan penelitian kualitatif deskriptif. Sampel dalam penelitian ini adalah pengurus KONI, pelatih, dan atlet, yang berjumlah sebanyak 10 orang. Populasi dalam penelitian ini yaitu memasuki situasi sosial tertentu, melakukan observasi dan wawancara kepada orang-orang yang dipandang mengetahui tentang situasi sosial tersebut. Teknik pengambilan sampel menggunakan purposive sampling, sedangkan teknnik pengumpulan data menggunakan observasi, wawancara dan dokumentasi (triangulasi). Teknik analisis data yang digunakan dalam penelitian ini dengan menggunakan reduksi data, penyajian data dan menarik kesimpulan. Berdasarkan hasil penelitian ini maka peneliti menyimpulkan bahwa prestasi cabang olahraga yang terdaftar di KONI Kabupaten Paser masih sangat minim, dikarenakan memiliki 42 cabang olahraga yang resmi terdaftar di sekretariat KONI, namun dari 42 cabang olahraga tersebut, hanya memiliki 5 cabang yang menjadi unggulan sesuai dengan keriteria yang telah ditetapkan oleh pihak KONI terkait prestasi yang diraih harus secara kontiyu dan berkelanjutan, berikut cabang olahraga yang menjadi unggulan KONI Kabupaten Paser ialah : (1). Renang, (2). Dayung, (3). Sepak Takraw, (4). Tarung Derajat dan (5). Taekwondo.

Kata Kunci : Prestasi dan Cabang Olahraga Unggulan

\section{Pendahuluan}


Koni Paser saat ini menanungi 42 cabang olahraga yang resmi terdaftar namun melihat banyaknya cabang olahraga yang sudah terdaftar tidak sesuai dengan keadaan sarana dan prasarana yakni sebagai salah satu penunjang dalam pelaksanaan latihan yang sesuai dengan standar, sehingga akan berpengaruh terhadap kualitas atlet tersebut. Sarana dan prasarana yang belum merata terhadap cabang olahraga hingga saat ini masih terlihat begitu jelas, dibuktikan dengan adanya bangunan seperti gedung olahraga dan tempat olahraga lainnya yang sangat minim, sehingga belum dapat menampung sesuai jumlah cabang olahraga yang aktif hingga saat ini, terutama cabang olahraga yang mengharuskan menggunakan fasilitas seperti gedung dalam proses latihan. Meskipun memiliki banyak keterbatasan namun atlet tersebut tetap konsisten serta berusaha dengan cara latihan tetap serius dan semangat sehingga harapan kedepannya ketika pemerintah melihat hasil prestasi dari cabang olahraga tersebut bisa lebih memperhatikan apa saja yang menjadi kekurangan didaerah terutama dalam bidang olahraga. Namun dengan demikian terdapat beberapa pengurus cabang olahraga yang lebih menyampingkan masalah keterbatasan mulai dari sarana dan prasarana hingga kurangnya perhatian dari pemerintah sama halnya tidak menglami kekurangan dalam kebutuhan saat latihan, dengan tetap konsisten atlet tersebut berlatih dengan serius serta memakai alat-alat seadanya yang masih tersedia dan yang masih bisa digunakan serta terkadang pelatih mengeluarkan biaya untuk membeli alat penunjang latihan yang baru, pelatih berupaya melakukan berbagai macam cara agar atlet tidak terpengaruh dengan adanya keadaan seperti ini, dan akhirnya beberapa cabang olahraga yang gigih berlatih mendapatkan hasil yang cukup maksimal dalam berbagai event perlombaan atau pertandingan, namun beberapa cabang olahraga lainnya memperoleh hasil yang belum maksimal. Adapun data terkait cabang olahraga berprestasi dilihat dari hasil pertandingan popprov dan porprpov maka terdapat beberapa cabang olahraga yang selalu memperoleh medali yakni, (1). Renang (PRSI), (2). Dayung (PODSI), (3). Sepak takraw (PSTI), (4). Tarung derajat, (5). Taekwondo (TI). Kelima cabang olaharaga inilah yang menjadi pundi-pundi untuk mendapatkan medali saat mengikuti perlombaan atau pertandingan. Dari beberapa cabang olahraga yang terdaftar sebagai olahraga yang diunggulkan oleh koni, maka peneliti akan mendalami terkait prestasi apa saja yang diraih oleh cabang olahraga tersebut. Bagaimana bisa mendapatkan hasil yang begitu baik dengan keterbatasan yang ada, dan faktor apa saja yang 
mempengaruhi dalam peningkatan prestasi sehingga beberapa cabang olahraga ini masuk kedalam daftar cabang olahraga unggulan Koni Kabupaten Paser.

Berdasarkan latar belakang diatas penulis termotivasi untuk mengadakan penelitian dengan judul "Survei Prestasi Cabang Olahraga Unggulan Koni Kabupaten Paser".

\section{1) Tujuan penelitian}

Berdasarkan rumusan masalah yang dikemukakan diatas, untuk mengetahui Prestasi Cabang Olahraga Unggulan Koni Kabupaten Paser.

\section{2) Manfaat Penelitian}

Berdasarkan dari Latar Belakang, Rumusan Masalah dan Tujuan Penelitian, maka diharapkan hasil penelitian ini bermanfaat untuk :

1. Manfaat Teoritis

Penelitian ini diharapkan dapat memberi pengetahuan tentang survei prestasi cabang olahraga unggulan koni Kabupaten Paser pada pengembangan program pendidikan jasmani.

2. Manfaat Praktis

a. Mahasiswa Pendidikan Olahraga Jasmani Kesehatan Dan Rekreasi Universitas Mulawarman, dapat memberikan pengetahuan dan sebagai sumber informasi tentang prestasi cabang olahraga unggulan KONI Kabupaten Paser.

b. Komite Olahraga Nasional Indonesia, sebagai bahan masukan agar tidak hanya terfokus pada cabang olahraga unggulan, namun berlaku untuk semua cabang olahraga..

c. Masyarakat, sebagai bahan informasi dan pengetahuan tentang prestasi apa saja yang diraih cabang olahraga sehingga menjadi unggulan.

d. Peneliti selanjutnya, diharapkan penelitian ini dapat menjadi referensi penelitian dan menjadikan referensi untuk judul yang akan menjadi bahan perbandingan dalam melakukan penelitian selanjutnya.

e. Peneliti, penelitian ini dapat dijadikan sebagai aplikasi ilmu yang didapat di Fakultas Keguruan Dan Ilmu Pendidikan Universitas Mulawarman Samarinda. 


\section{Kajian Pustaka}

Survei adalah suatu cara yang dapat digunakan seseorang atau suatu kelompok untuk mendapatkan suatu informasi dari informan berupa fenomena atau suatu keadaan yang dimana belum diketahui kejelasannya secara pasti.

Prestasi adalah suatu pencapaian dengan tingkatan hasil secara maksimal meliputi dari segi pendidikan, kesenian dan olahraga.

Organisasi adalah kelompok orang-orang yang berada disuatu lingkup tertentu dengan berbagai pemikiran yang berbeda-beda namun tetap fokus untuk mencapai satu tujuan yang telah disepakati bersama.

Koni adalah satu-satunya organisasi keolahragaan nasional yang berwenang dan bertanggung jawab mengelola, membina, mengembangkan dan mengoordinasi setiap dan seluruh pelaksanaan kegiatan olahraga prestasi setiap anggota diwilayah hukum Negara Kesatuan Republik Indonesia. Koni didalam melakukan kegiatannya yang berhubungan dengan dunia olahraga internasional dapat berkoordinasi dengan lembaga terkait.

Suatu cabang olahraga dapat dikatakan unggulan apabila telah memiliki suatu prestasi baik prestasi daerah maupun nasional, serta cabang olahraga tersebut memiliki prestasi secara berkelanjutan, sebagai contoh : dalam setiap event cabang olahraga tersebut dapat memperoleh medali atau naik podium sebagai juara, regenerasi atlet yang terus menerus dapat dikembangkan, adanya pembinaan yang jelas, sehingga dasar pengkategorian menjadi cabang olahraga akan didasari melalui prestasi yang akan terus berjalan dengan baik dari prestasi junior maupun senior (Sumber : Sekretariat Koni Paser).

Koni merupakan satu-satunya organisasi keolahragaan nasional yang berwenang dan bertanggung jawab mengelola, membina, mengembangkan dan mengoordinasi setiap dan seluruh pelaksanaan kegiatan olahraga prestasi setiap anggota diwilayah hukum Negara Kesatuan Republik Indonesia. Pembinaan olahraga yang sistematis serta sumber daya manusia yang berkualitas dapat diarahkan pada peningkatan pengendalian diri, tanggung jawab, disiplin dan sportivitas. 
Prestasi merupakan hasil upaya maksimal yang dicapai olahragawan atau kelompok olahragawan (tim) dalam kegiatan olahraga. Prestasi merupakan suatu bagian yang membanggakan ketika seseorang atau kelompok memperoleh hasil pencapaian secara optimal. Prestasi yang dicapai akan berpengaruh terhadap pola latihan yang harus menyesuaikan dengan keterbatasan yang ada, meskipun memiliki keterbatasan akan tetapi KONI Kabupaten Paser masih mempunyai beberapa cabang olahraga yang menjadi unggulan dan harapannya cabang olahraga inilah yang menjadi pundi-pundi untuk mendapatkan medali. Dengan dasar pemikiran tersebut, dalam penelitian ini pengambilan judul "Survei Prestasi Cabang Olahraga Unggulan Koni Kabupaten Paser". Tujuan penelitian ini adalah untuk mengetahui bagaimanakah prestasi cabang olahraga unggulan KONI Kabupaten Paser.

\section{Metode Penelitian}

1). Teknik Pengumpulan Data

Penelitian ini menggunakan teknik triangulasi yaitu merupakan teknik pengumpulan data yang menggabungkan dari berbagai teknik pengumpulan data dan sumber data yang telah ada.

2). Jenis Penelitian

Penelitian ini menggunakan jenis penelitian kualitatif deskriptif. Penelitian kualitatif digunakan untuk meneliti pada kondisi obyek secara alamiah, serta peneliti adalah sebagai instrumen kunci, teknik pengumpulan data dilakukan secara triangulasi (gabungan), analisis data bersifat induktif dan hasil penelitian kualitatif lebih menekankan makna dari pada generalisasi.

\section{3). Definisi Operasional}

Definisi operasional untuk menggambarkan bentuk penelitian yang akan dilakukan sehingga dapat memberi gambaran kepada peneliti terkait yang akan diteliti. Fokusan dari peneilitan ini adalah :

1. Prestasi 
Prestasi dapat dibuktikan baik secara lisan maupun tertulis; piagam, dokumentasi dan medali.

2. Cabang olahraga

Cabang olahraga yang masuk kedalam kategori unggulan dapat dibuktikan berdasarkan catatan prestasi yang diraih baik tingkat daerah, provinsi, maupun nasional, secara kontiyu atau berkelanjutan.

4). Teknik Analisis Data

1. Reduksi Data (Data Reduction)

Reduksi data berarti merangkum, memilih hal-hal yang pokok, memfokuskan pada hal-hal yang penting, dicari tema dan polanya dan membuang yang tidak perlu.

2. Penyajian Data (Data Display)

Penyajian dalam penelitian kualitatif dapat dilakukan dalam bentuk uraian singkat, bagan, hubungan antar kategori (flowchart) dan sejenisnya. Yang paling sering digunakan untuk menyajikan data dalam penelitian kualitatif adalah dengan teks yang bersifat naratif.

3. Kesimpulan (Conclusion Drawing)

Kesimpulan dalam penelitian kualitatif yang diharapkan adalah merupakan temuan baru yang sebelumnya belum pernah ada. Temuan dapat berupa deskripsi atau gambaran suatu objek yang sebelumnya masih belum jelas, sehingga setelah diteliti akan menjadi jelas.

\section{Hasil dan Pembahasan}

\section{A. Hasil Penelitian}

\section{Reduksi Data}


Mereduksi data berarti merangkum atau memilih hal-hal yang pokok, memfokuskan pada hal-hal yang penting. Dengan demikian data yang telah direduksi akan memberikan gambaran yang lebih jelas dan mempermudah peneliti untuk melakukan pengumpulan data selanjutnya.

\section{a. Observasi}

Adapun hasil observasi yang peneliti lakukan di Koni Kabupaten Paser memperoleh data cabang olahraga prestasi pada pekan olahraga pelajar provinsi (popprov) mulai dari tahun 2014, 2016, 2018, dan daftar cabang olahraga yang mengikuti event kejuaraan daerah, kejuaraan provinsi, kejuaraan prapon, kejuaraan pon. Dari data tersebut terdapat lima cabang olahraga prestasi yang menjadi unggulan Koni Kabupaten Paser yaitu, (1). Renang, (2). Dayung, (3). Sepak Takraw, (4). Tarung Derajat dan (5). Taekwodo.

\section{b. Wawancara}

Adapun hasil wawancara yang peneliti lakukan, tentunya terdapat beragam jawaban yang diberikan informan kepada peniliti melalui wawancara tersebut, adapun informan yang terlibat dalam wawancara yang dilakukan peneliti, yakni ketua koni (Bapak TS) dan sekretaris koni (Bapak MI), pelatih cabang olahraga Renang (ZA), cabang olahraga Dayung (MY), cabang olahraga Sepak Takraw (MI), cabang olahraga Tarung Derajat (S) dan cabang olahraga Taekwondo (S), dan atlet cabang olahraga Renang (RA), atlet cabang olahraga Dayung (A), atlet cabang olahraga Sepak Takraw (W), atlet cabang olahraga Tarung Derajat (S), atlet cabang olahraga Taekwondo (S).

\section{c. Dokumentasi}

Adapun hasil dokumentasi yang peneliti dapatkan meliputi, prestasi yang diraih selama kurang lebih lima tahun terakhir dan bukti-bukti seperti piagam serta dokumentasi pada saat penelitian.

\section{Penyajian Data}


Dalam hal ini peneiliti menyajikan data hasil wawancara dari beberapa informan yaitu, Pengurus Koni, Pelatih dan Atlet cabang olahraga unggulan Koni Kabupaten Paser. Hasil wawancara tersebut merupakan salah satu cara untuk mengetahui prestasi apa saja yang diraih sehingga bisa menjadi cabang olahraga unggulan Koni Kabupaten Paser.

\section{a. Pengurus KONI}

Merupakan sekumpulan orang yang berada di dalam struktur organisasi KONI, serta memiliki tugas yang berbeda-beda sesuai dengan bidangnya masingmasing, namun memiliki satu tujuan yang sama. Selain terlibatnya dalam kepengurusan KONI mereka memiliki kesibukan yang berbeda-beda yakni pekerjaan dan lain sebagainya sehingga penulis hanya mewawancarai ketua dan sekretaris KONI sebagai perwakilan dari seluruh anggota KONI, karena kedua pengurus tersebut merupakan jantung dari kepengurusan internal KONI Kabupaten Paser. Adapun pertanyaan-pertanyaan dan hasil pada saat wawancara yaitu :

prestasi cabang olahraga yang terdaftar di KONI masih sangat minim, dikarenakan memiliki 42 cabang olahraga yang resmi terdaftar di sekretariat KONI, namun dari 42 cabang olahraga tersebut, hanya memiliki 5 cabang yang di unggulkan sesuai dengan keriteria yang telah ditetapkan oleh pihak KONI terkait prestasi yang diraih harus secara kontiyu dan berkelanjutan.

\section{b. Pelatih Cabang Olahraga}

Pelatih cabang olahraga merupakan suatu hal yang terpenting didalam pembinaan, dengan demikian sumber daya manusia pada pelatih itu sendiri berperan penting dalam menjalankan suatu program yang nantinya akan dilaksanakan oleh masing-masing atlet dengan mencapai tujuan yaitu mendapatkan presatsi setinggi-tingginya. Adapun pertanyaan-pertanyaan dan hasil pada saat wawancara yaitu : 
Kelima cabang olahraga tersebut memiliki catatan prestasi yang sangat baik dan kontiyu dan dapat dibuktikan dengan bukti fisik seperti piagam, medali dan penghargaan lainnya. Namun adapun beberapa kendala seperti perhatian dari pemerintah masih sangat minim, sehingga pelatih berinisiatif untuk mengeluarkan dana secara mandiri demi berjalannya pembinaan di masingmasing cabang olahraga tersebut dan beberapa atlet lainnya memiliki kesibukan lainnya, seperti pekerjaan, kuliah dan lain sebagainya.

\section{c. Atlet Cabang Olahraga}

Merupakan inti dari cabang olahraga berprestasi yang menjadi unggulan di KONI, tanpa adanya atlet maka jelas tidak akan ada prestasi yang diraih dan tugas atlet yaitu mendapatkan prestasi setinggi-tingginya sehingga cabang olahraga memiliki pencapaian yang sangat baik serta tetap mengedapankan pola latihan secara rutin dan regenerasi atlet tetap dipertahankan. Adapun pertanyaapertanyaan dan hasil wawancara, yaitu :

Kelima cabang olahraga yang menjadi unggulan memiliki kemampuan yang baik dalam mengatur waktunya, serta kemauan yang tinggi dalam memperoleh prestasi, dibuktikan dengan pola latihan yang sangat disiplin dan inisiatif mereka yang menambah latihan sendiri, dan juga ketekunan saat mereka berlatih. Sehingga atlet-atlet tersebut mendapatkan prestasi yang lebih baik dan lebih unggul dari cabang olahraga lainnya.

\section{B. Pembahasan}

Pembahasan yang disampaikan disini adalah untuk memaparkan apa yang telah diperoleh peneliti dari hasil penelitian lapangan yang bertujuan untuk mengetahui tentang cabang olahraga apa saja yang menjadi unggulan dan prestasi apa saja yang telah diraihnya sehingga bisa dikategorikan ke dalam kategori unggulan KONI Kabupaten Paser. Dengan demikian pembahasan ini dilakukan secara khusus pada masing-masing fokusan dalam penelitian ini yaitu :

a. Prestasi cabang olahraga renang 
Catatan cabang olahraga renang berhasil memperoleh prestasi dari berbagai event, pretasi yang diperoleh yakni : (1). Kejurda pada tahun 2016 mendapatkan juara III, (2). Poprov pada tahun 2016 mendapatkan juara III, (3). O2SN pada tahun 2016 mendapatkan juara juara III, (4). Kejurprov pada tahun 2017 mendapatkan juara I sebanyak dua kali yakni gaya dada 50m dan 100m, mendapatkan juara II sebanyak tiga kali yakni gaya bebas $100 \mathrm{~m}$ dan $50 \mathrm{~m}$, serta $50 \mathrm{~m}$ gaya kupu, mendapatkan pula juara III sebanyak dua kali yakni gaya 100m gaya kupu dan 100m gaya punggung, (5). Kejurda pada tahun 2015 mendapatkan juara III sebanyak dua kali yakni 50m dan 100m gaya kupu, (6). Balikpapan open pada tahun 2017 mendapatkan juara I sebanyak dua kali yakni 200m gaya dada dan 100m gaya dada, mendapatkan juara II, mendapatkan juara III sebanyak tiga kali yakni 200m gaya bebas, 100m gaya kupu dan 400m gaya ganti, (7). Kejurprov pada tahun 2018 mendapatkan juara I sebanyak tiga kali yakni 100m gaya dada, 50m gaya kupu, 50m gaya dada, mendapatkan juara II sebanyak empat kali yakni $400 \mathrm{~m}$ gaya bebas, 200m gaya dada, 100m gaya kupu, 200m gaya ganti, mendapatkan juara III 100m gaya bebas.

\section{b. Prestasi cabang olahraga dayung}

Catatan prestasi yang diraih oleh dayung ialah: (1). Porprov pada tahun 2014 mendapatkan juara I dargon boat 22org/tim, (2). Porprov pada tahun 2018 mendapatkan juara I sebanyak dua kali yakni dragon boat 22org dan dragon boat 12org, mendapatkan juara II kayak slalom, (3). Mahakam international pada tahun 2016 mendapatkan juara III.

\section{c. Prestasi cabang olahraga sepak takraw}

Cabang olahraga sepak takraw memiliki beberapa catatan prestati yang di raih yaitu : (1). Popprov pada tahun 2014 mendapatkan juara I, (2). popprov pada tahun 2016 mendapatkan juara II, (3). popprov pada tahun 2018 mendapatkan juara II, (4). Kejurprov dan praporprov pada tahun 2017 mendapatkan juara II, (5). Porprov pada tahun 2018 mendapatkan juara II, (6). Kejurprov dan seleksi prapon pada tahun 2019 mendapatkan juara II sebanyak dua kali dan juara III sebanyak dua kali. 
d. Prestasi cabang olahraga tarung derajat

Catatan prestasi yang telah diraih yaitu: (1). Porprov pada tahun 2014 mendapatkan juara I, (2). Kejurprov pada tahun 2015 mendapatkan juara I, (3). Pra-porprov pada tahun 2017 mendapatkan juara I, (4). Porprov pada tahun 2018 mendapatkan juara I, (5) kejurnas pada tahun 2019 mendapatkan juara III.

e. Prestasi cabang olahraga taekwondo

Catatan prestasi yang telah diperoleh hingga saat ini kebanyakan (1). kejuaraan antar club seKabupaten paser, (2). Porprov pada tahun 2014 mendapatkan juara III dan (3). Porprov pada tahun 2018 mendapatkan juara II.

Cabang olahraga yang menjadi unggulan adalah suatu cabang olahraga yang telah masuk dalam cabang olahraga berarti telah memenuhi kriteria sesuai dengan ketentuan yang telah disepakati pihak KONI, yakni memiliki catatan prestasi yang baik dan berkelanjutan karena perkembangan olahraga tersebut dilihat secara langsung perkembangannya dan prestasinya melalui KONI (Sumber: Sekretariat Koni Paser).

\section{a. Cabang olahraga Renang}

Cabang olahraga renang memiliki atlet sebanyak 16 orang terdiri dari 8 orang putri dan 8 orang putera keseluruhan dari mereka yaitu terdiri dari pelajar sekolah dasar dan sekolah menengah pertama, adapun perekrutan atlet yang dilakukan melalui induk cabang olahraga renang lalu kemudian berkomunikasi secara langsung dengan masingmasing orang tua yang telah mengarahkan anaknya untuk mengikuti kegiatan olahraga renang. Pola latihan yang dilakukan memiliki jadwal mulai hari senin hingga hari jum'at yang dilaksanakan pada pukul 15:00 wita sampai dengan pukul 17:15 wita, dengan waktu latihan lima kali dalam satu minggu

b. Cabang olahraga Dayung :

Cabang olahraga dayung memiliki atlet sebanyak kurang lebih 100 orang terdiri dari puteri dan putera diantaranya atlet nomor dragon boat 22org dan 12org, kayak slalom 1org, 2org dan 4 org. Sebagian dari mereka masih bersekolah, dan sebagian lainnya dari mereka telah sibuk dengan masing-masing pekerjaannya. Adapun latihan yang 
dijadwalkan ketika tidak menghadapi pertandingan satu hingga dua kali dalam seminggu namun jika menjelang pertandingan maka mereka berlatih lima hari dalam seminggu bahkan bisa bertambah hingga menjadi tujuh hari sesuai dengan waktu yang dipersiapkan. Perekrutan yang diakukan oleh cabang olahraga dayung yakni menyeleksi dari beberapa club didaerah maupun penyeleksian pada masing-masing individu meliputi kondisi fisik calon atlet hingga kekuatan dan teknik dalam melakukan dayungan.

\section{c. Cabang olahraga Sepak Takraw}

Cabang olahraga sepak takraw memiliki atlet sebanyak 12 orang terdiri dari putera, beberapa atlet pada cabang olahraga sepak takraw ini masih bersekolah dan beberapa lainnya telah berkuliah maupun bekerja. Perekrutan atlet pada cabang olahraga sepak takraw bekerjasama dengan beberapa sekolah didaerah dan mengadakan beberapa event kejuaraan agar nantinya pengcab dapat melihat langsung kemampuan atlet itu sendiri, serta beberapa orang yang biasanya diarahkan oleh orang tua mereka untuk mengikuti latihan di tempat latihan pengcab.

\section{d. Cabang olahraga Tarung Derajat}

Cabang olahraga tarung derajat memiliki jumlah atlet 10 orang terdiri dari putera dan puteri beberapa atlet diantaranya masih bersekolah dan beberapa lainnya telah memiliki kesibukan bekerja, perekrutan atlet pada cabang olahraga tarung derajat ini lebih kepada pendekatan kepada warga sekitar yang awalnya hanya ingin mencoba, namun lama kelamaan barulah terbentuk untuk menjadi atlet, klasifikasinya yaitu, mau mencoba dan pantang menyerah. Jadwal latihan pada cabang olahraga tarung derajat dalam satu minggu satu hingga dua hari, namun jika mendekati event kejuaraan maka bisa mencapai lima kali dalam seminggu.

e. Cabang olahraga Taekwondo

Cabang olahraga taekwondo memiliki jumlah atleh 10 orang terdiri dari putera dan beberapa diantaranya masih bersekolah didaerah, untuk perekrutan pada cabang olahraga taekwondo dilaksanakan secara terbuka karena kebanyakan atlet yang datang sebelumnya diarahkan oleh masing-masing orang tua untuk ikut berlatih di cabang 
olahraga taekwondo. Latihan yang telah dijadwalkan untuk saat ini dilaksanakan pada malam rabu dan malam sabtu, pukul 20.00 wita sampai dengan pukul 22.00 wita.

\section{Kesimpulan dan Saran}

\section{A. Kesimpulan}

1. prestasi cabang olahraga yang terdaftar di KONI Kabupaten Paser masih sangat minim, dikarenakan memiliki 42 cabang olahraga yang resmi terdaftar di sekretariat KONI, namun dari 42 cabang olahraga tersebut, hanya memiliki 5 cabang yang di unggulkan sesuai dengan keriteria yang telah ditetapkan oleh pihak KONI terkait prestasi yang diraih harus secara kontiyu dan berkelanjutan, berikut cabang olahraga yang menjadi unggulan KONI Kabupaten Paser ialah : (1). Renang, (2). Dayung, (3). Sepak Takraw, (4). Tarung Derajat dan (5). Taekwondo.

2. Cabang olahraga unggulan, pembinaan di kelima cabang olahraga ini terstruktur dengan baik, dengan adanya jadwal latihan yang tidak monoton, perekrutan atlet yang transparan, dan keadaan atlet yang baik dibuktikan melalui jawaban dari setiap pertanyaan diajukan kepada atlet dan pelatih, serta regenerasi atlet dimasing cabang olahraga sangat diperhatikan sehingga prestasi yang diraih hingga saat ini lebih unggul.

\section{B. Saran}

1. Untuk cabang olahraga unggulan, agar kedepannya bisa terus mempertahankan prestasinya dan bila perlu makin ditingkatkan prestasinya sehingga tetap menjadi olahraga yang diunggulkan khususnya di regional Kalimantan Timur.

2. Untuk cabang olahraga yang belum masuk kedalam kategori unggulan, agar kedepannya lebih memperhatikan kepada proses pembinaan di masing-masing cabang olahraga, serta dapat terus memotivasi atle-atletnya agar dapat memeiliki 
jiwa bersaing sehingga kedepannya dapat membuktikan bahwa cabang olahraga tersebut bisa mendapatkan prestasi setinggi-tingginya dan tentunya dapat bergabung kedalam kategori unggulan demi mengangkat nama daerah khususnya Kabupaten Paser.

3. Koni Kabupaten Paser, sebagai tempat naungan dari setiap cabang olahraga agar kedepannya Koni dapat memantau secara langsung terkait pembinaan di masingmasing cabang olahraga sehingga dapat mengetahui sejauh mana perkembangan cabang olahraga tersebut serta terus memotivasi cabang olahraga yang belum menjadi unggulan maupun cabang olahraga yang telah menjadi unggulan sehingga persaingan akan semakin baik dan prestasinya dapat lebih meningkat.

4. Pemerintah daerah, harapan kedepannya tingkat kepedulian pemerintah dapat meningkat, dikarenakan potensi atlet dicabang olahraga yang berada di Paser memiliki potensi yang sangat baik, tentunya selain mengharapkan dari potensi yang sudah ada, tidak lupa juga perhatian dari pemerintah sangat diharapkan oleh masing-masing cabang olahraga di Kabupaten Paser.

\section{DAFTAR PUSTAKA}

[1] Ahmadi, Ruslam 2016. Metodelogi Penelitian Kualitatif. Yogyakarta:Ar-Ruzz Media.

[2] Azra Abuzar, dkk 2015, Metode Penelitian Survei. Bogor:In Media

[3] Giriwijoyo, Santoso \& Sidik, Dikdik Zafar 2013. Ilmu Faal Olahraga (Fisiologi Olahraga). Bandung:PT. Remaja Rosdakarya Offiset [4] Harsuki, 2013. Pengantar Manajemen Olahraga. Jakarta: PT. Raja Grapindo Persada [5] Morissan, dkk 2012. Metode Penelitian Survei. Jakarta:Kencana Prenada Media Group

[6] Presiden Republik Indonesia 2005, Undang-Undang No.3 Tentang Sistem Keolahragaan Nasional. 
[7] Subkhi, Akhmad \& Jauhar, Muhammad 2013. Pengantar Teori \& Prilaku Organiasi. Jakarta:P.T Prestasi Pustakaraya

[8] Sugiyono 2013. Memahami Penelitian Kualitatif. Bandung:Alfabeta

[9] Sekertariat Koni 2014, ADART (Anggaran Dasar Anggaran Rumah Tangga) KONI. Kabupaten Paser:Koni Paser

[10] Wursanto, Ig 2005. Dasar-Dasar Ilmu Organisasi. Yogyakarta:C.V Andi Offset

[11] http://www.artikelsiana.com/2017/11/pengertian-prestasi-macam-prestasi.html\#. (diakses tanggal 26 februari 2019)

[12] http://qmc.binus.ac.id/2014/10/28/in-d-interview-wawancara-mendalam/ (diakses tanggal 20 mei 2019) 